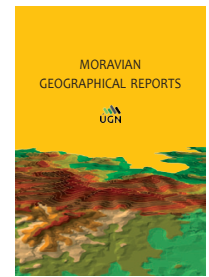

MORAVIAN GEOGRAPHICAL REPORTS

The Czech Academy of Sciences, Institute of Geonics

journal homepage: http://www.geonika.cz/mgr.html

doi: https://doi.org/10.2478/mgr-2021-0018

\title{
The geography of demilitarisation: Do regional economic disparities affect the spatial distribution of military base closures?
}

\author{
Jan ŽENKA ${ }^{a}{ }^{*}$, Bohuslav PERNICA ${ }^{b}$, Jan KOFROŇ $^{c}$
}

\begin{abstract}
Very few researchers have focused on the question of: if and to what extent, regional economic disparities affect military base closures. In this paper, we aim to explain regional patterns of military base closures in the Czech Republic, a country that has experienced a sharp decline in military employment and expenditures since the beginning of 1990s. Three groups of predictors of closure were considered: local (size, age, location and hierarchical position of the military base); regional (wages, unemployment, city size, the initial level of militarisation of the district); and national-level predictors (geostrategic priorities and restructuring of the Czech Armed Forces). Our research is informed by the theory of public choice and its application to the decision-making processes concerning military base closures and realignments. We employed a combination of regression models to determine which group of the above-mentioned factors affected the spatial distribution of military bases in the period 1994-2005. While geostrategic factors (such as distance from the border with West Germany) and restructuring of the army (type of a military base) were the most important, regional economic disparities showed no significant correlation with the intensity of military base closures/downsizing. We did not demonstrate that military bases in economically lagging regions had been systematically protected in the Czech Republic.
\end{abstract}

Keywords: defense, demilitarisation, military base closure, peace dividend, regional disparities, Czech Republic

Article history: Received 11 November 2020, Accepted 5 November 2021, Published 31 December 2021

\section{Introduction}

In many European countries, the end of the Cold war resulted in a widespread process of demilitarisation due to two primary reasons. First, signatories to the Treaty on Conventional Armed Forces in Europe (CFE Treaty) were obliged to reduce the strength of their military to ceilings agreed to in Paris on November 19, 1990, until 1995. Secondly, many post-socialist countries continued their demilitarisation beyond 1995, in a response to radically changed geopolitical conditions and their integration into NATO and the European Union. Finally, this trend resulted in a shift from conscripted armed forces to All-Volunteer Forces in the 2000 s, leading to further reduction of the armed forces.

Considering that the "frontline" of the Cold War cut Central Europe (CE) in half, it comes as no surprise that Central European states experienced an extensive demilitarisation in the 1990 s and early 2000 s. The countries reduced their military strength in terms of personnel and equipment to such an extent that they went considerably below the $\mathrm{CFE}$ ceilings, and their military underwent substantial structural changes. In response to the NATOrelated obligations (participation in out-of-region military operations) and the emerging threat of international terrorism, the countries prioritised lighter, strategically more mobile, forces. Simply, CE countries radically changed the size and structure, as well as geographical distribution of their armies.

There are several reasons to focus on the Czech Republic as a case study of this process. Firstly, the military in the Czech Republic was downsized at an unprecedented pace (see Section 2). Secondly, as Czechoslovakia was

\footnotetext{
a Department of Human Geography and Regional Development, Faculty of Science, University of Ostrava, Czech Republic (*corresponding author: J. Ženka, e-mail: jan.zenka@osu.cz)

${ }^{b}$ Institute of Administrative and Social Sciences, Faculty of Economics and Administration, University of Pardubice, Pardubice, Czech Republic

${ }^{\mathrm{c}}$ Institute of Political Studies, Faculty of Social Sciences, Charles University, Praha, Czech Republic
} 
at the very frontline of the Cold War, the geographical distribution of its troops was extremely west-skewed (Štaigl and Turza, 2013a, b; Pernica, 2020). With the end of the Cold War and the disappearance of foes endangering the sovereignty of the Czech Republic, the existing geographical pattern of troop distribution had to change profoundly. The end of the Cold War was quickly followed by a sequence of transformative geopolitical events and processes in the region (the implementation of the CFE treaty, the break-up of Czechoslovakia in 1993, the NATO enlargement in 1999 , and the EU enlargement in 2004). Finally, these changes took place within the context of profound socio-economic transformation and an economic slowdown in the early to mid-1990s.

The transformation - even if successful on a broader plane - resulted in an increase of regional disparities in employment and economic performance (Blažek and Csank, 2007; Ženka et al., 2015), and the financially challenged government struggled to directly support the lagging regions. In such a situation the government may opt for indirect support. This may include keeping military bases in struggling regions. Thus, one could hypothesise (along with Huck, 1994) that the governments should have been less willing to close the military bases in the struggling regions because their presence could be beneficial for local employment and buying power. While regional economic disparities in the Czech Republic were not considered to be a vital problem until the late 1990s, the situation has changed since the mid-1990s. Therefore, regional policy might have had certain effects on the process of military base closures and realignments, especially between 1998 and 2005 when social democrats were in power. From this perspective, the Czech Republic offers an interesting testing ground for an empirical investigation of the various structural factors strategic, organisational, as well as economic - influencing regional differences in demilitarisation.

In summary, the main goal of our study is to explain spatial differences in the demilitarisation of the Czech Republic between 1994 (when there still lingered a network of military installations originally intended for the operations of the Czechoslovak front in the context of the Cold War) and 2005 (the year after the abandonment of conscription and the concentration of troops in a few, so-called, prospective municipalities). We focus on an estimation of the impact of several potentially important structural factors determining the governmental decisions on the distribution of forces over the territory by military bases (MBs) closures: military (geostrategic), operational factors and non-military factors, focusing on the potential effect of regional economic disparities.

More specifically, in this paper, we aim to answer three research questions. Firstly, we ask if and to what extent did regional policy affect the spatial pattern of demilitarisation: can we observe any systematic tendency to keep a military presence in economically lagging regions? In other words, is there any association between regional economic performance/employment in 1994 and the pace of demilitarisation between 1994 and 2005, controlling for the effects of geographical distance from the border with Bavaria? Did economically lagging districts experience a lower intensity of demilitarisation than their betterperforming counterparts, ceteris paribus? Secondly, was there any observable effect of the MBs hierarchy on the intensity of demilitarisation at the district level? Were districts with a higher share of colonels and generals more resistant to military personnel reductions? Thirdly, was there any systematic tendency to concentrate military personnel (military bases) into larger cities to improve the possibilities of recruitment?

To answer these questions, our analysis employs OLS multivariate regression methods conducted at the district level.

\section{A geography of demilitarisation - theoretical background}

When considering the geographical or regional aspects of demilitarisation, three major avenues of researching this topic can be distinguished:

i. The spatial division of labour and tasks in the defence industry;

ii. Regional economic, social, or environmental effects of the MBs closures or reintegration of the former military training areas into a regional system; and

iii. Geographical and other relevant factors of the MBs closures.

Focusing more on the manufacturing of armaments than on MBs per se (see Tab. 1), the first group of studies deals with the changing (post)Cold-War geographies of the defence sector. These authors document a relatively sharp NorthSouth polarity in the United Kingdom, characterised by the concentration of high-tech production, R\&D and other strategic functions in the South and West of England. Atkinson (1993) and Warf (1997) document a similar spatial division of labour and tasks in the United States, showing high militarisation of the coastal high-tech metropolitan regions of California and New England. Therefore, a large share of the military employment cuts during the 1980s and 1990s occurred in economically developed metropolitan regions that were able to recover quickly from the economic shock.

The most widespread studies are those that focus on regional economic, social, and environmental impacts of the MBs closures. Scholars dealing with these issues often agree that the negative effects of the MBs closures on regional employment and income were rather limited, which was documented for example in the U.S. (Atkinson, 1993; Bradshaw, 1997; Hooker and Knetter, 1999; Poppert and Herzog, 2003; Lee, 2016), Germany (Paloyo et al., 2010), Sweden (Andersson et al., 2005), and in Central and Eastern Europe (Myrttinen, 2003). Marginal regions of the former military training areas are analysed relatively frequently. Several papers focus on their prospects of development (Seidl and Chromý, 2010), ecological value and land-use patterns (Havlíček et al., 2018), or local community perception (Frantál et al., 2020).

While papers dealing with the geographical or regional aspects of demilitarisation are relatively numerous, there are very few studies focusing directly on the geographical (or even regional economic) factors leading to the MBs closures. Beaulier et al. (2011) is a notable exception, documenting that the MBs in high unemployment U.S. states were less likely to be put on the list of MBs considered for closure. On the other hand, MBs in high unemployment counties were more likely to be closed. While there are several research contributions dealing with the factors of MBs closures in the USA, empirical evidence from Central and Eastern Europe (CEE) is rare (with some exceptions, such as Hercik, 2016). Therefore, we aimed to fill this gap and focused not on regional economic effects of $\mathrm{MB}$ 


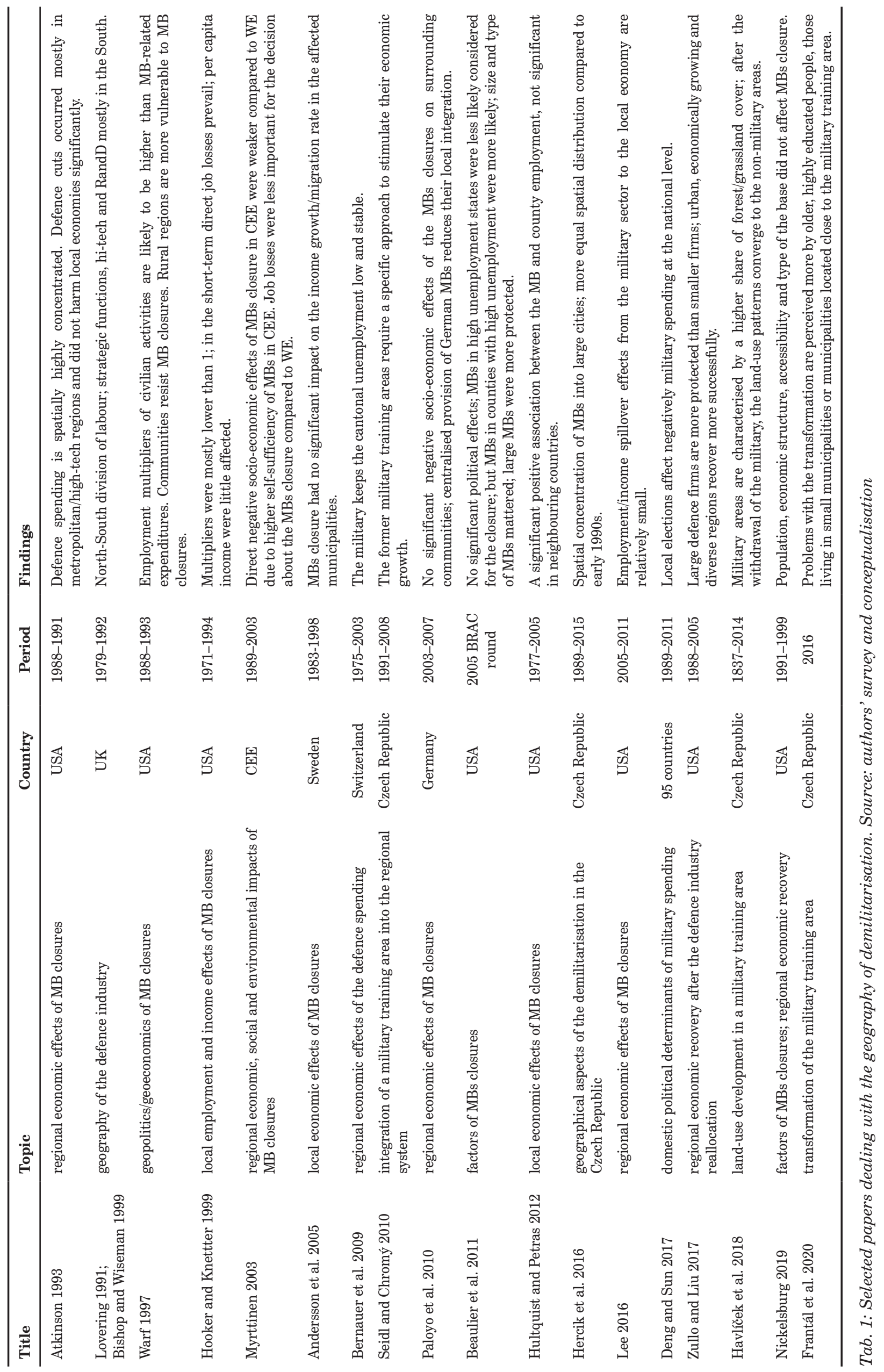


closures, but on the reverse relationship: regional economic disparities and policies as a predictor of MB closures in the Czech Republic.

In general, decisions to close or not to close an $\mathrm{MB}$ are determined by factors operating at three different geographical scales: (i) local (individual MBs); (ii) regional (district) level; and at the (iii) national level (Beaulier, Hall and Lynch, 2011).

All three factors are naturally shaped by prospects of developments in the international situation (geopolitics). Decisions taken at the local level may be determined more by (inter)national factors than by the condition of individual military bases. Hereinafter, we describe briefly crucial factors that are characteristic for different scales. We consider only variables that might be relevant for the demilitarisation of the Czech territory; also, not all issues discussed in the theories framing the papers presented in Table 1 are included (e.g. prospects of naval or nuclear bases).

At the national level, two principal factors shaping regional patterns of demilitarisation also at lower hierarchical levels, can be distinguished: geostrategic priorities and the restructuring of the military. Changing geostrategic priorities (often resulting from geopolitical changes at the international level) should be theoretically the most significant factor of MB closures and downsizing, because they reflect military interests embodied in operational planning, in fact. The end of the Cold War in the early 1990s was so potent that it resulted not only in a reduction of defence spending but to some extent reduction and reallocation of MBs in the U.S. (Atkinson, 1993), in Western Europe (Lovering, 1991), in the UK (Bishop and Gripaios, 1995), in the CEE (Hercik, Szcyrba and Fňukal, 2011; Hercik, 2016; Kiss, 1993; 2000; Smith, 1994) and in the Community of Independent States (the former Soviet Union). From the Czech point of view, the concentration of troops close to the border with the Federal Republic of Germany was neither necessary nor sustainable after the collapse of socialism. Therefore, the initial level of militarisation can be an important predictor of MB closures.

Changes in geostrategic orientation were usually followed by the restructuring of the military. Fundamental changes are evident, such as the reduction of offensive military capabilities, e.g. supersonic bombers, tank divisions, heavy artillery, etc., development of expeditionary military capabilities needed for peacekeeping, a curb on conscription, and a shift to AVF (All-Volunteer Force) made some military bases redundant or too costly (Warf, 1997; Paloyo, Vance and Vorell, 2010). The type of a military base affects the probability of its closure or downsizing (Beaulier, Hall and Lynch, 2011). According to this paradigm - in the context of the Czech Republic - heavily mechanised (and their support) units, (i.e. artillery, tanks, heavy infantry, etc.) should be closed or downsized more likely than other types of MBs, because they were over-represented in the Coldwar Czechoslovak People's Army due to the tasks given to Czechoslovakia in the Warsaw Treaty Organization (Dvorak and Pernica, 2021).

At the regional (district) level, demographic and socioeconomic variables come into play: urban size, regional economic performance, unemployment, and the initial level of militarisation. The MBs tend to concentrate in large cities (Atkinson, 1993) due to the residential preferences of their employees and to capitalise on urbanisation economies related to urban size/density, such as the availability of a skilled labour force and a dense network of suppliers.
Atkinson (1993) documented a shift of defence spending in the U.S.: from the industrial Midwest towards New England and California. This shift was to large extent technologically driven: an increasing share of electronics and other hightech instruments and components in the weapon systems supported concentration of defence spending in economically growing metropolitan regions, where those high-tech suppliers were located. Similar trends (North-South shift) were documented in the United Kingdom (Bishop and Wiseman, 1999). On the other hand, military bases in or close to large cities may be less protected, because larger cities are more able to absorb unemployment resulting from closures and productively reuse former military land and buildings (Zullo and Lu, 2017).

To some extent, regional patterns of demilitarisation may be shaped significantly by regional policies. Districts with high unemployment rates and low wage levels should be protected from a large-scale military base closure or downsizing to avoid social and political tensions. Another reason for the protection of military bases in high unemployment districts is the local labour market: possibilities for military recruitment are better than in economically well-performing areas (Bäckström, 2019). Also, the operation of military installations in peripheral or economically stagnating regions with low per capita incomes and low costs of living can be cheaper than in higher cost locations (Wheeler, 2016).

On the other hand, in economically well-performing regions with expanding real estate markets, there is a better chance to sell the military property and a higher probability of a successful revitalisation of military brownfields. Last but not least, the quality of life associated with urban amenities and environmental attributes is also important for the successful operation of military installations, and is one of the selection criteria for military base closure or realignment (Rašek, 2002; Wheeler, 2016). Therefore, some peripheral, rural or old industrial regions may be threatened by a military base closure more than economically well-performing (urban, metropolitan) regions promising higher standards of living (Bradshaw, 1999; Fortuna, Teixeira and Silva, 2021).

Districts with a high initial level of militarisation at the beginning of the restructuring period may have excessive military capacities that need to be downsized. On the other hand, political representatives of the districts most dependent on military bases may support military spending at the national level (suggested by the Military-Industrial Complex Theory: Cobb, 1969, 1976; Lindsay, 1991) and prevent military bases closures in their electoral districts (Frawley, 2006).

At the local level, four basic factors related to the characteristics of a military base may be distinguished: size, age, location (at the local level), and position of the military base in the hierarchy of the Czech Armed Forces (see Tab. 2)

Size should negatively affect the probability of a military base closure (Beaulier, Hall and Lynch, 2011) for two reasons: (i) scale economies associated with the operation of larger military bases, smaller bases may not be able to operate efficiently; and (ii) higher exit sunk costs that make the closure of large bases too expensive (see Clark and Wrigley, 1997; Melachroinos and Spence, 2001 for the conceptualisation of sunk costs).

The latter is related not only to the size but also to the age and location of the military base (Wheeler, 2016). Older military bases in worse technical conditions with obsolete 


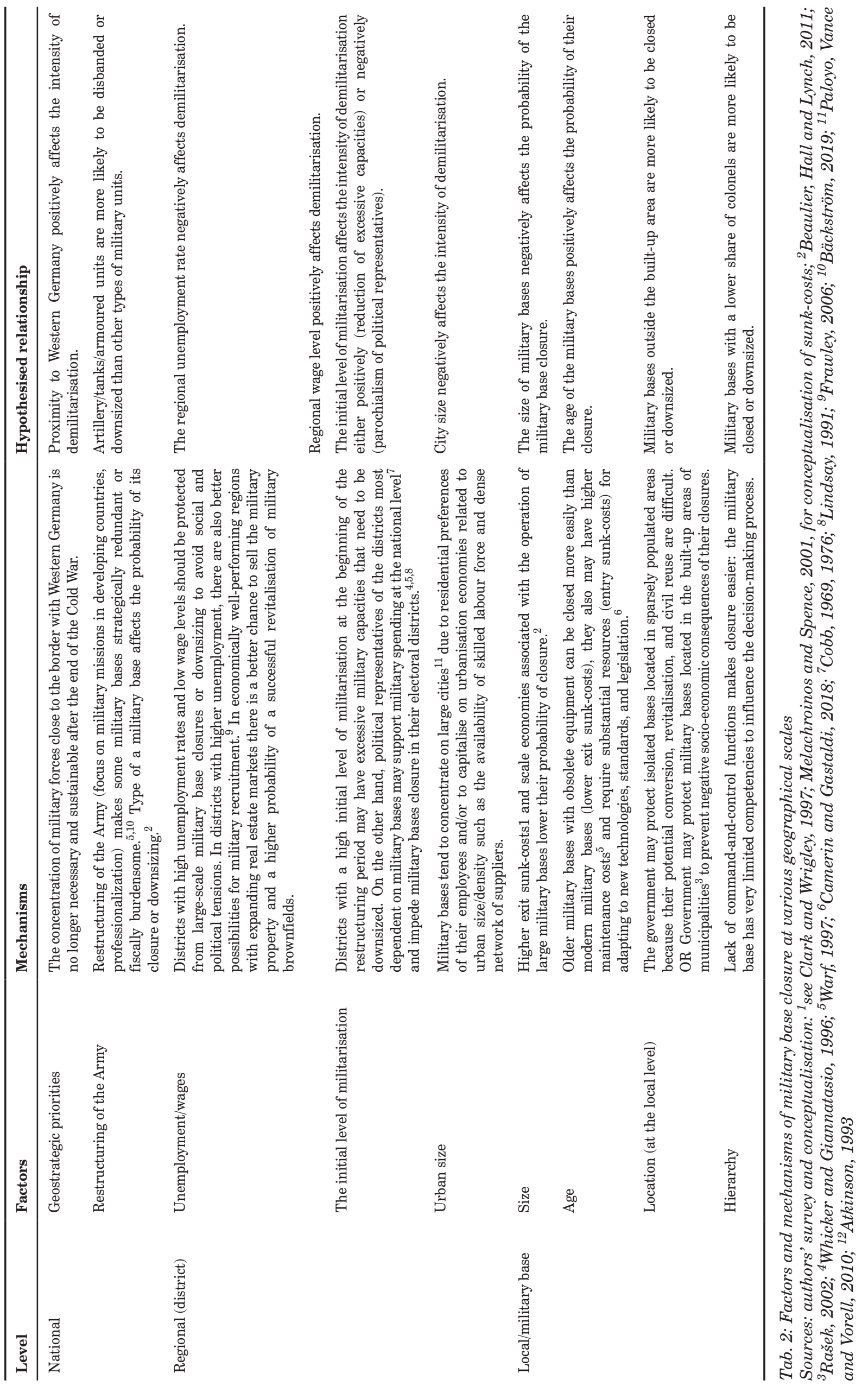


equipment can be closed more easily than modern military bases, without incurring high exit sunk costs. They also may have higher maintenance costs (Warf, 1997; Wheeler, 2016) and may require substantial resources (entry sunk costs) for adapting to new technologies, standards, and legislation (Camerin and Gastaldi, 2018). Bases located in the builtup areas of cities or municipalities can be protected from closure (Rašek, 2002) to prevent negative social and economic phenomena associated with potential brownfield formation to occur. On the other hand, military bases located in isolated areas are more difficult to sell and convert for civilian purposes. The effect of location is thus not straightforward. The position of a military base (or a unit) in the hierarchy of the Czech Armed Forces matters for its prospects of survival. Bases concentrating command and control functions should be less susceptible to closure or downsizing, while bases lacking these functions can hardly control their fate.

Considering a more general approach, public choice theory (Olson, 1971) offers a theoretical framework that might be useful for an explanation of general patterns and individual decisions whether to close a military base or not. His classical argument, as applied to the issue of MB closures, says that a reform aiming to change a system of dispersed (military) costs and concentrated benefits (local employment, multiplier effects of an MB) will fail (Beaulier et al., 2011) Parochialism and/or rent-seeking behaviour (Kehl, 2003) of the interest groups at local, regional or national level (municipalities, deputies, corporations in the defence sector, etc.) benefitting from the local MB, will resist any reform of the military complex at a national level that would at the end lead to more dispersed benefits and (spatially) concentrated costs. Our research is thus informed by public choice theory, but we are unable to operationalise and test this theory. To do so, an inquiry into the decision-making process would be necessary to validate the findings and assumptions based on the spatial analysis.

\section{Context, data, and methods}

In this prospect, demilitarisation in the CEE region can be divided into three periods. The first one, the early postCold War period, was associated with a peacetime dividend defined as a reduction of manpower and equipment to meet the CFE ceilings by 1995 (Sadykiewicz, 1987). The second period was driven by relief of the geopolitical situation in response to a reduction of Russian influence over the CEE region in the 1990s and NATO enlargement in 1999 (McCausland, 1999). The third period was characterised by an unfailing demand for military volunteers deployable in UN peacekeeping in the 1990s. The demand grows stronger after the 9/11 attack and the NATO deployment in Iraq and Afghanistan (Edmunds, 2006). So, many NATO countries opted for small AVFs. If compared with the Cold War situation, since 2001 the military has shifted towards forces composed of professional soldiers sourced by light equipment and integrated with the military that induce almost no reserves for a case of conventional war (Edmunds, 2006). Simply, the 'Global War on Terror' has boosted the transition from the high intensity conventional combat-oriented armies based on mass conscription - to light, small and professional AVFs.

As highly militarised frontline states, the Czech Republic (as part of the former Czechoslovakia) and East (and West) Germany enjoyed a unique position in this transition. Yet, the situation of the Czech Republic was more specific. Three major features characterised the Czech military in the first half of the 1990s, after the peaceful split of Czechoslovakia and the withdrawal of roughly 85,000 Soviet troops in 1991:

i. Excessive military capacities in terms of military employment, bases, infrastructure, weapons and arms manufacturing capacities;

ii. An unsuitable structure of the army - a high share of tanks, artillery and heavily mechanised units, and

iii. The high spatial concentration of the military bases and troops along the border with the former West Germany (see Fig. 1).

The changing geopolitical and geo-economic nexus required a significant reduction, restructuring and reallocation of the army and the military complex. Military downsizing was driven also by the discarding of obsolete Soviet weaponry and partly by a general unwillingness of the Czech government to spend more on defence. As Figure 2 illustrates, the investigated period (1994-2005) covers the years of intensive demilitarisation. The reason why we prefer to start our investigation in 1994 is that the rather abrupt dissolution of Czechoslovakia (1993) led to a dramatic process of the relocations of military units (and equipment) during late 1992 and early 1993.

Apart from the geostrategic and operational factors, the decisions about the MB closures were also driven by domestic political and economic developments. Although the economic situation in the early transformation period was rather favourable (despite the downturn in 1990-1992) and absolute regional disparities in wages and unemployment remained low (Blažek, 1996; Tomeš, 1996), the situation started to deteriorate in the second half of the decade. In the period 1996-2000, the national unemployment rate increased from 3.5 to $8.8 \%$ and regional economic disparities grew rapidly (Blažek and Csank, 2007). In 2002 (when the plan to end conscription and to adopt an AVF was announced), there was a sharp polarity between the "successful" regions (metropolitan regions: see (Smetkowski, 2013), regional capitals and several non-metropolitan industrial regions that obtained a high amount of foreign direct investment (Ženka et al., 2015) and laggards with a high unemployment rate, represented by structurally affected old industrial regions and rural regions (Hampl and Müller, 2011; Baštová, Hubáčková and Frantál, 2011; Blažek and Csank, 2007).

Coincidentally, while the previous right-wing government did not see present or future regional economic (and social) disparities as a principal problem, the new social-democratic government ruling since 1998 had at least an ideologically different attitude. Thus, one wonders if this change in attitude has affected decisions, given the geographical aspect of army reform in the late 1990s and the early $2000 \mathrm{~s}$. In addition, the fact that the Czech Republic has not faced any serious security threat between 1993 and 2005 (Kř́iž, 2021) means that the economic factors should be more easily identified.

Apart from the theoretical arguments mentioned in the previous section, we considered several factors that might explain regional patterns of the 1994-2005 demilitarisation: (i) the initial level of militarisation in 1994; (ii) the geostrategic location of a military base; (iii) regional economic performance; (iv) position of the military bases in the organisational hierarchy of the Czech Armed Forces; (v) urban size; and (vi) type of region. Each factor was represented by just one quantitative indicator (regional economic performance by two indicators): all were calculated at the level of districts (former LAU2: local administrative units), not at the level of individual military bases. 


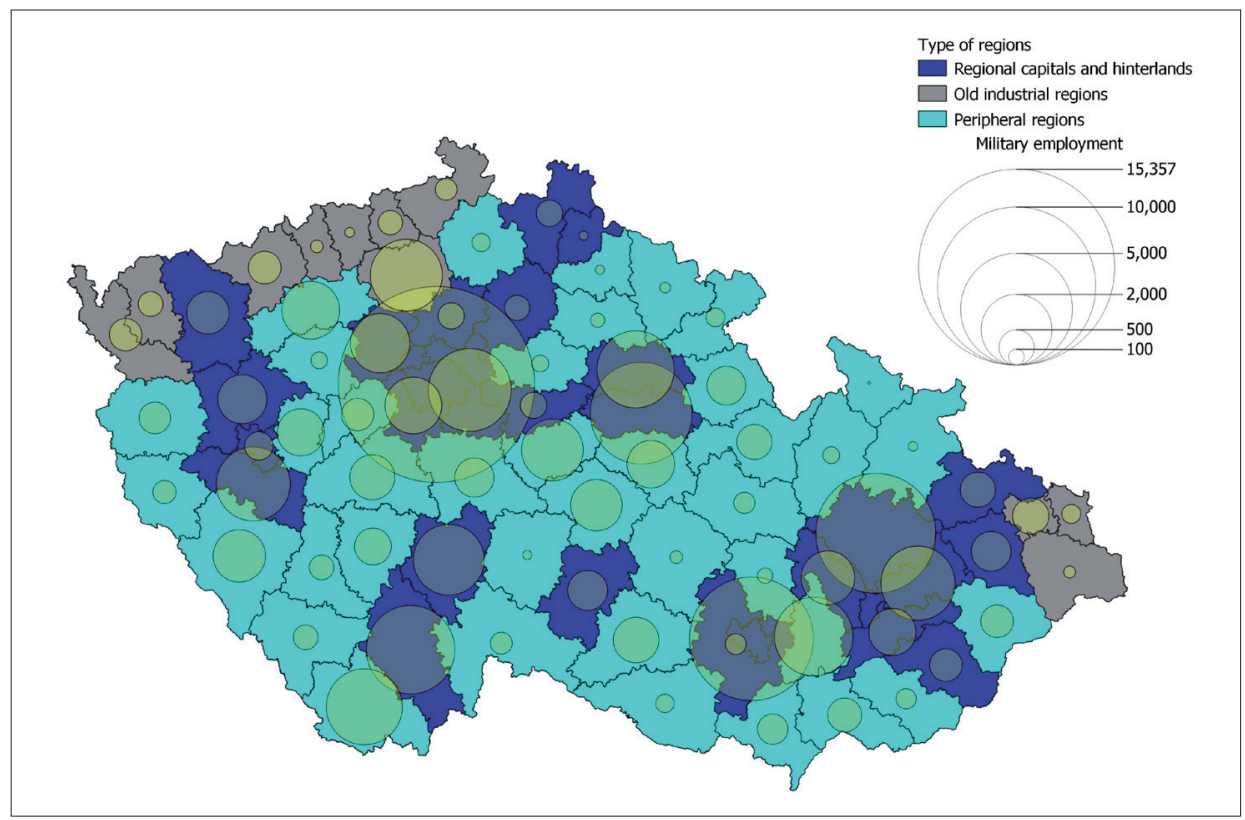

Fig. 1: Regional distribution of military employment in 1994 Source: Data: Ministry of Defence 2020; authors' elaboration

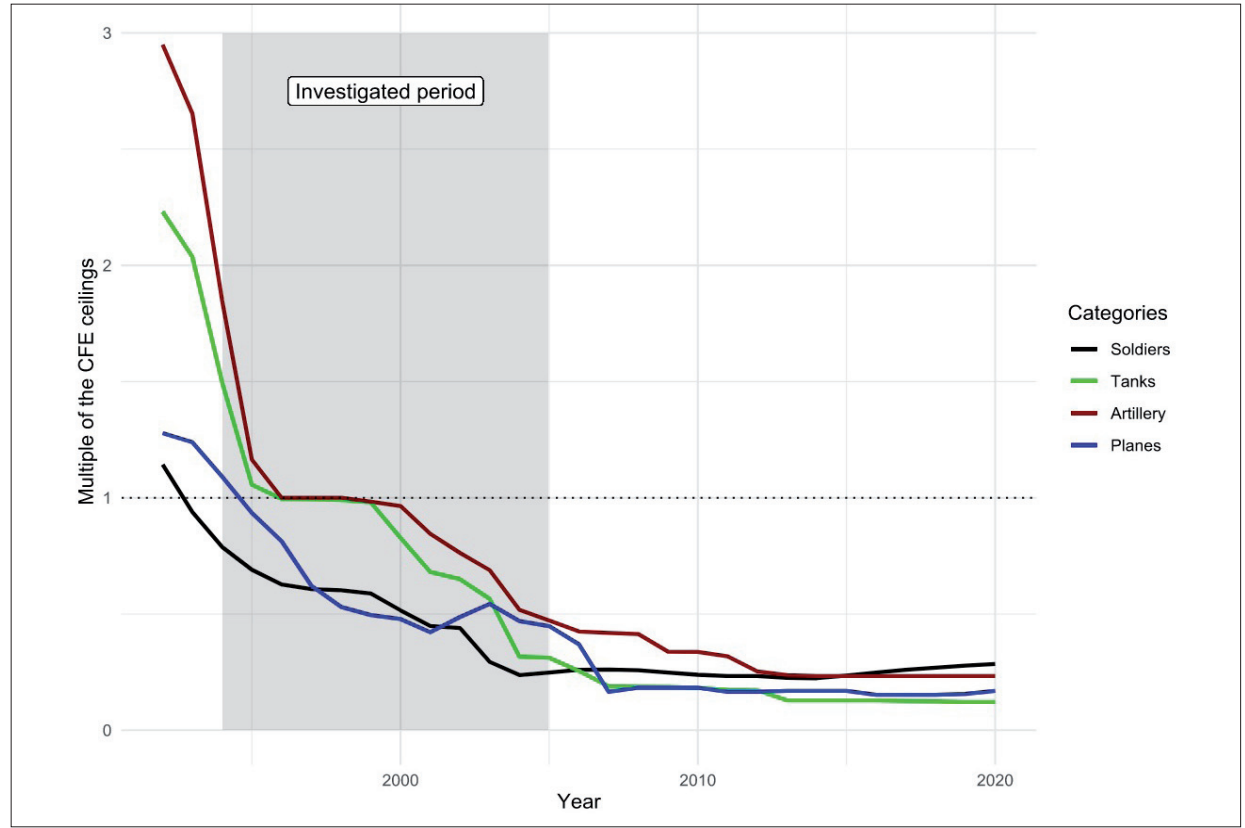

Fig. 2: Restructuring of the Czech army: military equipment as a multiple of the CFE ceilings and defence expenditures (CZK m.) on ground force and air force, 1992-2019 (Jan 1)

Source: Statistical Yearbook of the Czech Republic (1993-2020); Prague, Czech Statistical Office; Ministry of Defence, 2020; authors' compilation

The dependent variable: "Change in militarisation", was measured as the number of professional soldiers and civil employees in 2005 minus the number of professional soldiers and civil employees in 1994 in a district. The position of a military base in the hierarchy of the Czech Armed Forces is expressed as the number of generals and colonels. We also included the share of tanks, artillery, and/or armoured vehicle units in total military base staff to test the assumption that these military units were more likely downsized due to their excessive capacities in the 1990s.

The initial level of militarisation was measured by the number of professional soldiers and civil employees per capita in 1994 (see Tab. 3). This indicator is generally higher in sparsely populated peripheral regions than in large cities, ceteris paribus. Geo-strategic location can be operationalised by the distance of the military base from the border with former Western Germany. We used a simple proxy - the distance between the district town and the city of Nuremberg/Nürnberg in Bavaria.

Regional economic data (wages, unemployment) were obtained from the Appendix of (Hampl, 2005, p. 122-127). We tested not only the effects of regional wage and unemployment levels but also the type of region. A military base closure in peripheral, old industrial, and other economically lagging regions might have had severe socio-economic impacts on the local economy and social affairs. If regional policy was considered in the reorganisation of the Czech Armed Forces, wages should have had a positive and unemployment 


\begin{tabular}{|c|c|c|c|c|}
\hline Variable & Indicator & Abbrev. & Period & Data source \\
\hline Change in militarisation & $\begin{array}{l}\text { 1994-2005 change in the number } \\
\text { of professional soldiers and civil } \\
\text { employees }\end{array}$ & Percapdif & $1994-2005$ & MOD1, 1994; MOD2, 2005 \\
\hline Geostrategic location & $\begin{array}{l}\text { Distance between the district town } \\
\text { and Nuremberg }\end{array}$ & DistNur & 2018 & The Time Now \\
\hline Initial level of militarisation & $\begin{array}{l}\text { Number of professional soldiers and } \\
\text { civil employees per capita }\end{array}$ & X94percap & 1994 & $\begin{array}{l}\text { MOD1, 1994; MOD2, } \\
2005\end{array}$ \\
\hline \multirow[t]{3}{*}{ Regional economic performance } & $\begin{array}{l}\text { Average monthly wages per employee } \\
\text { (CZK) }\end{array}$ & Wages & 1994 & Hampl, 2005 \\
\hline & Unemployment rate $(\%)$ & Unemp & 1994 & Hampl, 2005 \\
\hline & Total annual wages per capita (CZK) & Econ_perform & 1994 & Hampl, 2005 \\
\hline Heavy units & $\begin{array}{l}\text { Share of the tank, artillery, and } \\
\text { armored vehicles units in the military } \\
\text { base staff }\end{array}$ & Heavy units & 1994 & MOD1, 1994; MOD2, 2005 \\
\hline \multirow[t]{2}{*}{ Organisational hierarchy } & $\begin{array}{l}\text { Share of generals and colonels in the } \\
\text { military base staff }\end{array}$ & Colonels & 1994 & $\begin{array}{l}\text { MOD1, 1994; MOD2, } \\
2005\end{array}$ \\
\hline & $\begin{array}{l}\text { Share of military officers in the } \\
\text { military base staff }\end{array}$ & Officers & 1994 & MOD1, 1994; MOD2, 2005 \\
\hline Urban size & $\begin{array}{l}1=\text { metropolitan region; } 0=\text { non- } \\
\text { metropolitan region (binary variable) }\end{array}$ & Metro region & 1991 & Hampl, 2005 \\
\hline Type of region & $\begin{array}{l}1=\text { regional capital; } 2=\text { old industrial } \\
\text { region; } 3=\text { peripheral region (nominal } \\
\text { variable) }\end{array}$ & Type-region & $1991-2005$ & $\begin{array}{l}\text { Hampl, 2005; Ženka, } \\
\text { Pavlík and Slach, } 2017\end{array}$ \\
\hline
\end{tabular}

Tab. 3: Indicators employed in the analysis of demilitarisation at the district level (Note: ${ }^{1}$ Simplified proxy for the distance between the military bases and the Czech-West German border)

Source: authors' compilation

a negative statistical effect on the dependent variable. While peripheral regions were characterised by low wages and high unemployment, old industrial regions (specialised in mining, metallurgy, and chemistry, for example) exhibited high unemployment rates, but also relatively high wage levels that were inherited from the socialist era (reflecting a strategic and ideological preference of mining and heavy manufacturing), For this reason we tested the effects of both wages and unemployment. In addition, peripheral and old industrial regions provide generally lower quality of life, amenities, and the potential of realignment. Therefore, it makes sense to focus not only on economic indicators but also on regional contexts.

The variable "urban size" may affect the regional level of militarisation in several ways. Firstly, military bases in large cities benefit from various mechanisms related to urbanisation economies (see Parr, 2002 for conceptualisation): large diversified labour markets and universities providing a plethora of skills relevant for the military, access to developed technical and transport infrastructure, or a broad variety of suppliers. Secondly, the residential attractiveness of large cities providing urban amenities for (potential) professional soldiers and civil employees may protect local military bases from closure. While these first two factors favour the survival of military bases in metropolitan regions, the third - the real estate market - may work against it. High property values and demand in large cities lower sunk costs associated with the military base closure and increase the probability of successful military brownfield regeneration. The variable 'urban size' is represented by a simple binary indicator that distinguishes between metropolitan and non-metropolitan regions (based on the regionalisation by Hampl, 2005).
The end of the Cold War, the collapse of the Soviet Union and the peaceful dissolution of the Warsaw Treaty Organisation resulted in radical changes in global geopolitics. These disruptions were most pronounced in the CEE theatre, which should have become a hot zone in a hypothetical total war between the democratic West and the communist East. During the Cold War, both communist and democratic nations in the CEE stood at the very frontline and thus they fielded large armies and accumulated substantial stockpiles of military hardware (TMB, 1989). Their mass militaries became a burden, in particular, with the end of socialism and the start of economic transformation (Roaf et al., 2014). Thus, the post-cold war demilitarisation was driven both by the force of the CFE treaty (see McCausland, 1995) and by the transition cost of economic transformation of the communist polity.

\section{Empirical results: the regression models}

In the previous sections, we have identified four sets of factors possibly influencing regionally unequal demilitarisation of the Czech Republic (strategic, organisational, regional development, and urban factors). There are good reasons to think that these factors could have affected the process of demilitarisation and relocation of the Czech Armed Forces within the Czech territory. To test these hypotheses, we have employed OLS regression in univariate and multivariate settings.

Univariate analysis revealed that only a few of the tested factors correlate with demilitarisation (Tab. 3). Unsurprisingly the initial level of militarisation correlated most with our dependent variable. This variable alone explained roughly half of the variance on the dependent 
variable. Some other factors correlated too (distance to Nuremberg, share of officers, unemployment, metropolitan region), but their explanatory power was limited (see Tab. 4). In addition, heteroscedasticity was an issue among some of these variables.

In the next step, we ran several multivariate models, where the previous level of militarisation played the role of the central variable to which other potentially relevant variables were added (Tab. 5). The previous level of militarisation showed a very robust association with the dependent variable. Inclusion of any other variables does not significantly alter the slope, range of Robust Standard Errors (RSE) or p values. On the other hand, most of the other previously statistically significant variables changed their slope quite a lot and their RSE became wider. In addition, $\mathrm{p}$-values rose well above 0.1 . Only two variables Metropol region and distance to Nuremberg showed some significance (above strict 0.05 thresholds but below the 0.1 more benevolent - threshold). Even more importantly, the change in their slopes was only modest. This indicates that these variables might play a role, albeit modestly.

What is interesting is that several potentially relevant variables displayed either no or inconsistent effects. Specifically, neither wages nor unemployment played a role in more complex additive models. Another interesting null finding is that organisational factors did not play a role. One would expect, that either the share of officers or top- echelon officers (generals and colonels) could predict the level of demilitarisation. Finally, it is remarkable that demilitarisation was not more pronounced in districts with a higher share of tank, heavy mechanised, artillery or antiaircraft units. These units were the cornerstone of the Cold War Czechoslovak Army. Nevertheless, the military utility of these units decreased with new security challenges. A focus on extra-regional operation after 2001 further reduced the need for heavy forces best suited for territorial defence. This is a paradox we will try to explain in a subsequent section, along with other key findings.

Given that 'Distance to Nuremberg' remained statistically significant even in more complex models and given its strong heteroscedasticity, we hypothesised that there might be an interaction effect between this variable and the initial level of militarisation. In such a setting, the initial level of militarisation would have been a conditioning variable affecting the effect of distance to Nuremberg (which sounds very plausible). Specifically, the interaction effect here would mean that the slope (magnitude of the effect) of the initial militarisation was stronger for regions closer to the ex-West-German border (see the red line in the Fig. 3) and weaker for regions far away from the border (see the blue line in Fig. 3).

The OLS regression with this interaction effect (see Tab. 6 and Fig. 3) provides support for this hypothesis. While there is a significant positive effect of the initial

\begin{tabular}{|c|c|c|c|c|c|c|c|c|c|c|}
\hline & Model 1 & Model 2 & Model 3 & Model 4 & Model 5 & Model 6 & Model 7 & Model 8 & Model 9 & Model 10 \\
\hline \multirow[t]{2}{*}{ (Intercept) } & $0.42^{* * *}$ & $0.42^{* * *}$ & $0.42^{* * *}$ & $0.42^{* * *}$ & $0.42^{* * *}$ & $0.42^{* * *}$ & $0.42^{* * *}$ & $0.42^{* * *}$ & $0.29^{* *}$ & $0.42^{* * * *}$ \\
\hline & $(0.06)$ & $(0.09)$ & $(0.09)$ & $(0.09)$ & $(0.09)$ & $(0.09)$ & $(0.09)$ & $(0.09)$ & $(0.10)$ & (0.09) \\
\hline \multirow[t]{2}{*}{ X94percap } & $0.60^{* * *}$ & & & & & & & & & \\
\hline & $(0.11)$ & & & & & & & & & \\
\hline \multirow[t]{2}{*}{ DistNur00 } & & $-0.21^{* *}$ & & & & & & & & \\
\hline & & $(0.08)$ & & & & & & & & \\
\hline \multirow[t]{2}{*}{ Heavy units } & & & -0.08 & & & & & & & \\
\hline & & & $(0.08)$ & & & & & & & \\
\hline \multirow[t]{2}{*}{ Colonels. } & & & & -0.04 & & & & & & \\
\hline & & & & $(0.06)$ & & & & & & \\
\hline \multirow[t]{2}{*}{ Officers } & & & & & $-0.24^{*}$ & & & & & \\
\hline & & & & & $(0.12)$ & & & & & \\
\hline \multirow[t]{2}{*}{ Econ. perform } & & & & & & 0.08 & & & & \\
\hline & & & & & & $(0.07)$ & & & & \\
\hline \multirow[t]{2}{*}{ Unemp } & & & & & & & $-0.18^{*}$ & & & \\
\hline & & & & & & & $(0.08)$ & & & \\
\hline \multirow[t]{2}{*}{ Wages } & & & & & & & & 0.19 & & \\
\hline & & & & & & & & $(0.13)$ & & \\
\hline \multirow[t]{2}{*}{ Metro_region } & & & & & & & & & $0.43^{*}$ & \\
\hline & & & & & & & & & $(0.21)$ & \\
\hline \multirow[t]{2}{*}{ Type_region } & & & & & & & & & & $-0.20^{*}$ \\
\hline & & & & & & & & & & $(0.10)$ \\
\hline Observations & 77 & 77 & 77 & 77 & 77 & 77 & 77 & 77 & 77 & 77 \\
\hline $\mathrm{R}$ squared & 0.58 & 0.07 & 0.01 & 0.00 & 0.09 & 0.01 & 0.05 & 0.06 & 0.06 & 0.07 \\
\hline
\end{tabular}

Tab. 4: Univariate regression models (dependent variable: Change in militarisation)

Notes: All continuous predictors are mean-centered and scaled by 1 standard deviation. Standard errors are heteroscedasticity robust; *** $p<0.001 ; * * p<0.01 ; * p<0.05$

Source: authors' computations 
level of militarisation on the subsequent demilitarisation, the effect was stronger among west Bohemian regions and substantially weaker in the case of regions located further away from the former "line of East-West military competition". Firstly, the interaction effect is statistically significant, and it has better explanatory power than additive OLS regression models. RSE's and confidence intervals are quite narrow, further increasing our belief in the interaction effect. Second, when the interaction effect is used, then the variable "Metropol region" remains statistically significant. In sum, it seems that the interaction effect model captures quite well the structural factors affecting Czech demilitarisation between 1994 and 2005. The initial level of militarisation interacting with the east-west gradient and the (metropolitan) character of a region provides a relatively good explanation (Fig. 3).

\begin{tabular}{|c|c|c|c|c|c|c|c|c|c|}
\hline & Model 1 & Model 2 & Model 3 & Model 4 & Model 5 & Model 6 & Model 7 & Model 8 & Model 9 \\
\hline \multirow[t]{2}{*}{ (Intercept) } & $0.42^{* * *}$ & $0.42^{* * *}$ & $0.42^{* * *}$ & $0.42^{* * *}$ & $0.34^{* * *}$ & $0.42^{* * *}$ & $0.35^{* * *}$ & $0.35 * *$ & $0.34^{* * *}$ \\
\hline & $(0.06)$ & $(0.06)$ & $(0.06)$ & $(0.06)$ & $(0.09)$ & $(0.06)$ & $(0.09)$ & $(0.09)$ & $(0.09)$ \\
\hline \multirow[t]{2}{*}{ X94percap } & $0.56^{* * *}$ & $0.58^{* * *}$ & $0.59^{* * *}$ & $0.59^{* * *}$ & $0.59^{* * *}$ & $0.59^{* * *}$ & $0.57^{* * *}$ & $0.56^{* * *}$ & $0.56^{* * *}$ \\
\hline & $(0.12)$ & $(0.11)$ & $(0.12)$ & $(0.11)$ & $(0.11)$ & $(0.12)$ & $(0.11)$ & $(0.12)$ & $(0.12)$ \\
\hline \multirow[t]{2}{*}{ DistNur00 } & -0.11 & -0.10 & & & & & -0.10 & -0.10 & -0.08 \\
\hline & $(0.06)$ & $(0.06)$ & & & & & $(0.05)$ & $(0.06)$ & $(0.05)$ \\
\hline \multirow[t]{2}{*}{ Officers } & -0.05 & & $-0,03$ & & & & & -0.03 & \\
\hline & $(0.07)$ & & $(0.06)$ & & & & & $(0.06)$ & \\
\hline \multirow[t]{2}{*}{ Unemp } & & & & -0.06 & & & & & -0.05 \\
\hline & & & & $(0.06)$ & & & & & $(0.06)$ \\
\hline \multirow[t]{2}{*}{ Metro region } & & & & & 0.24 & & 0.23 & 0.22 & 0.25 \\
\hline & & & & & $(0.12)$ & & $(0.12)$ & $(0.12)$ & $(0.13)$ \\
\hline \multirow[t]{2}{*}{ Type region } & & & & & & -0.06 & & & \\
\hline & & & & & & $(0.08)$ & & & \\
\hline Observations & 77 & 77 & 77 & 77 & 77 & 77 & 77 & 77 & 77 \\
\hline R squared & 0.59 & 0.59 & 0.58 & 0.58 & 0.60 & 0.58 & 0.61 & 0.61 & 0.61 \\
\hline
\end{tabular}

Tab. 5: Multivariate regression models (dependent variable: Change in militarisation)

Notes: All continuous predictors are mean-centered and scaled by 1 standard deviation. Standard errors are heteroscedasticity robust; $* * * p<0.001 ; * * p<0.01 ; * p<0.05$. Standard errors are in parentheses Source: authors' computations

\begin{tabular}{|c|c|c|c|c|c|}
\hline & Model 1 & Model 2 & Model 3 & Model 4 & Model 5 \\
\hline \multirow[t]{2}{*}{ (Intercept) } & $0.36^{* * *}$ & $0.30^{* * *}$ & $0.36^{* * *}$ & $0.36^{* * *}$ & $0.30^{* * * *}$ \\
\hline & $(0.06)$ & $(0.08)$ & $(0.06)$ & $(0.06)$ & $(0.08)$ \\
\hline \multirow[t]{2}{*}{ X94percap } & $0.54^{* * *}$ & $0.52^{* * *}$ & $0.54^{* * * *}$ & $0.53^{* * * *}$ & $0.52^{* * *}$ \\
\hline & $(0.08)$ & $(0.08)$ & $(0.08)$ & $(0.09)$ & $(0.08)$ \\
\hline \multirow[t]{2}{*}{ DistNur00 } & $-0.14^{* *}$ & $-0.14^{* *}$ & $-0.14^{*}$ & $-0.14^{* *}$ & $-0.14^{* *}$ \\
\hline & $(0.05)$ & $(0.05)$ & $(0.05)$ & $(0.05)$ & $(0.05)$ \\
\hline \multirow{2}{*}{$\begin{array}{l}\text { X94percap:Dist- } \\
\text { Nur00 }\end{array}$} & $-0.29 * * *$ & $-0.28^{* * *}$ & $-0.29 * * *$ & $-0.28^{* * *}$ & $-0.28^{* * *}$ \\
\hline & $(0.07)$ & $(0.07)$ & $(0.07)$ & $(0.07)$ & $(0.07)$ \\
\hline \multirow[t]{2}{*}{ Metro_region } & & $0.22^{*}$ & & & $0.22^{*}$ \\
\hline & & $(0.10)$ & & & $(0.10)$ \\
\hline \multirow[t]{2}{*}{ Unemp } & & & -0.02 & & \\
\hline & & & $(0.06)$ & & \\
\hline \multirow[t]{2}{*}{ Officers } & & & & -0.03 & -0.01 \\
\hline & & & & $(0.05)$ & $(0.05)$ \\
\hline Observations & 77 & 77 & 77 & 77 & 77 \\
\hline $\mathrm{R}$ squared & 0.69 & 0.71 & 0.69 & 0.69 & 0.71 \\
\hline
\end{tabular}

Tab. 6: Multivariate regression models with interactions (dependent variable: Change in militarisation)

Notes: Standard errors are in parentheses. All continuous predictors are mean-centered and scaled by 1 standard deviation. Standard errors are heteroscedasticity robust; *** $p<0.001 ; * * p<0.01 ; * p<0.05$

Source: authors' computations 


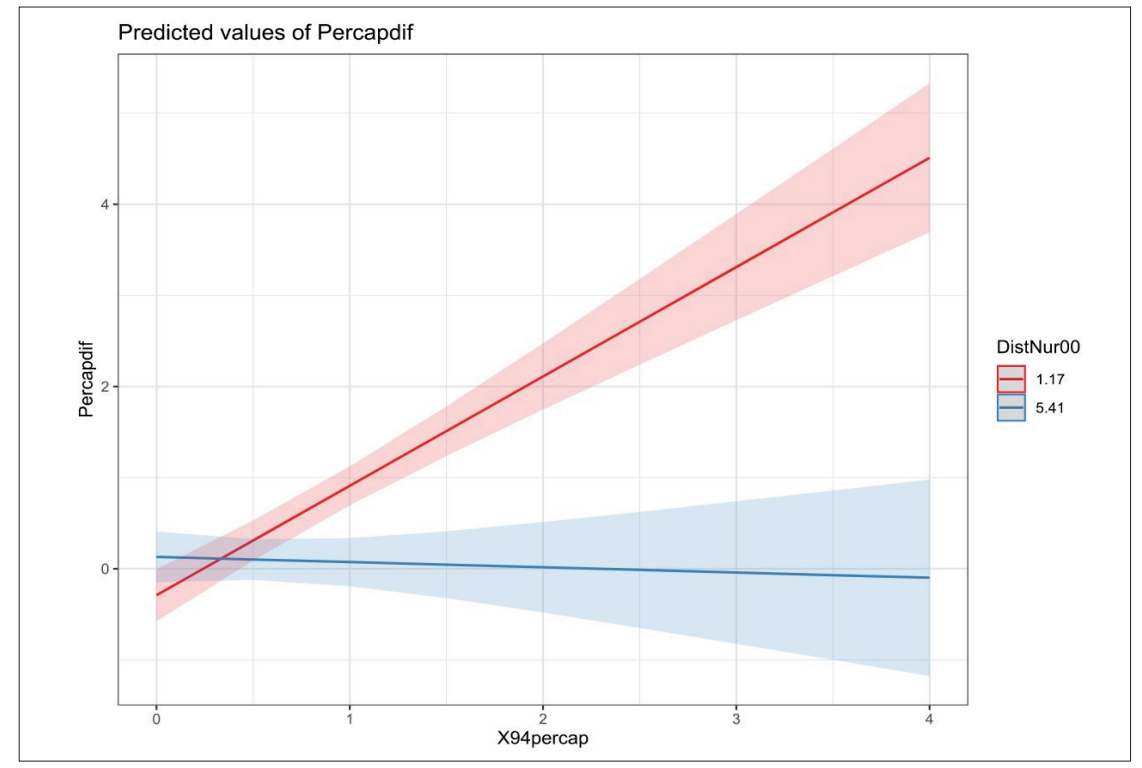

Fig. 3: Interaction effect of the Initial level of militarisation and the Distance from Nuremberg on the Change in militarisation. Notes: Percapdif $=1994-2005$ change in military employment; X94percap = military employment in 1994 per capita (district); SD indicates the standard deviation of a district's distance to Nuremberg (DistNur00) Source: authors' computations

While this model performs well in the sense of $\mathrm{R}^{2}, \mathrm{p}$ values and other model fit statistics, we understand that we are dealing with the population, not with a sample. Therefore, we decided to run bootstrapping (an iterated random selection of subsamples). Bootstrapping confirmed the robustness of our interaction model. Thus, we can conclude that our model is not driven by a few outliers. Speaking about specific cases, we focused on the cases deviating from the model: cases with high residuals. We also present basic changes in regional patterns of demilitarisation in the period 1994-2005.

Several high residual cases can be split into two groups. The first one includes cases that experienced rather a militarisation than demilitarisation or where the demilitarisation was surprisingly small. The other group comprises cases with unexpectedly high demilitarisation. The first group is to a large extent a by-product of its rarity. Only very few districts experienced militarisation between 1994 and 2005 (Fig. 4).

Thus, our OLS model (unsurprisingly) struggles with cases running counter the general tendency. Kutná Hora (the most deviant case) is an example here. During the Cold War, it was rather an unimportant district with a military airfield (Č́slav). Čáslav airport, however, has after several reforms become the location of one of the two major airbases of the Czech Air Force. It seems that the decision to locate a significant part of the air force at Č́slav was driven by its central location and advantageous weather conditions.

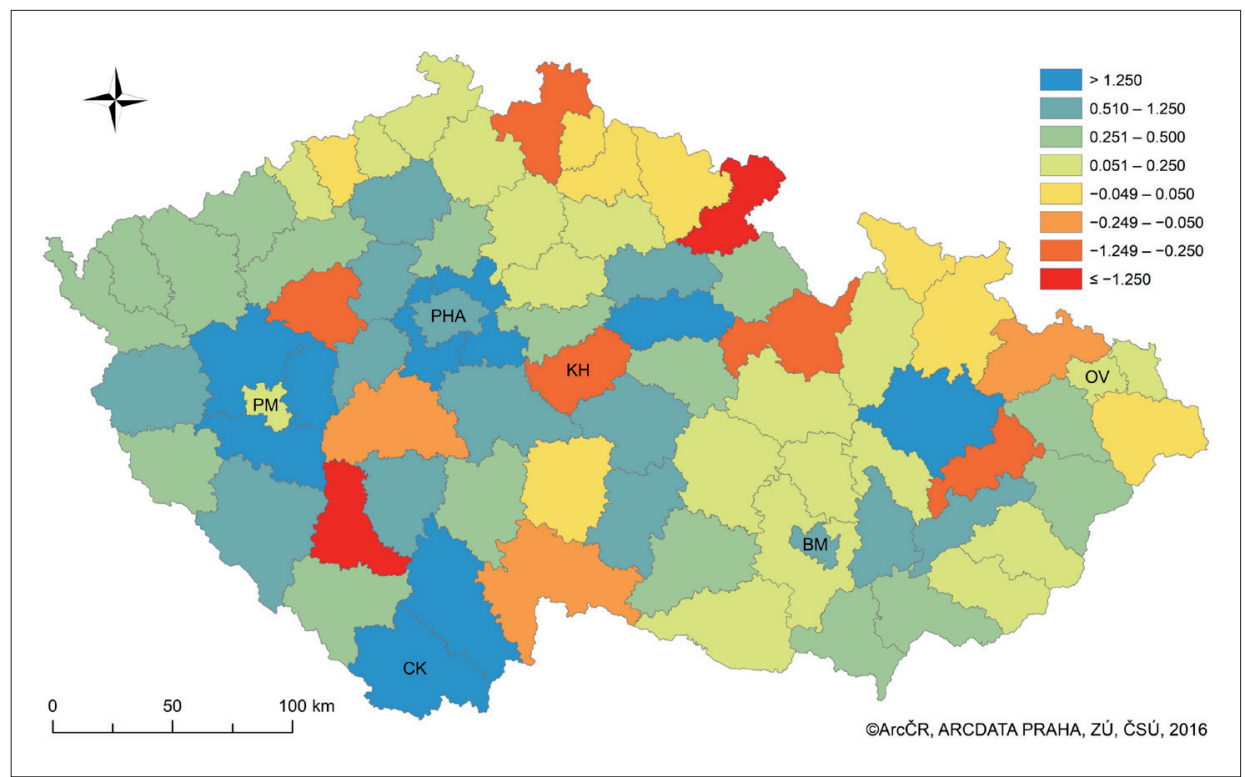

Fig. 4: Regional patterns of military employment reduction (1994-2005): relative changes. Notes: The map shows 1994 military employment divided by 2005 military employment. Blue districts showed the most rapid reduction of military employment, while in red districts military employment increased; PHA = Praha/Prague; $B M=$ Brno; $O V=$ Ostrava; $P M=$ Plzeň/Pilsen; $C K=$ Český Krumlov; KH = Kutná Hora.

Source: authors' compilation 
From the perspective of validity of our model, the second group of deviant cases is even more interesting. The most substantial positive residual pertains to Český Krumlov (peripheral district close to the Austrian border). This district had several hundred DoD employees in 1994, but in 2004 it had almost none (Fig. 5). Such a large demilitarisation is unique. The case has, however, a prosaic explanation. Due its vicinity to the military training area Boletice, Český Krumlov served as a place for the training of units for international UN missions in the 1990s. Furthermore, this ad hoc arrangement created units that were formally located in Český Krumlov. While most other battalions were built around the conscripts (officially not employees of the Ministry of Defence), units for UN missions were fully manned with professional soldiers or paid volunteers. Thus, in the mid-1990s, this district was nominally among the most militarised regions in the Czech Republic. With the accession to NATO and the shift to an All-Volunteer Force, the need for ad hoc solutions and the Český Krumlov base withered away; only the military training area remained. From this perspective, the unique role of Český Krumlov in the 1990s logically led to the closure of the local military base.

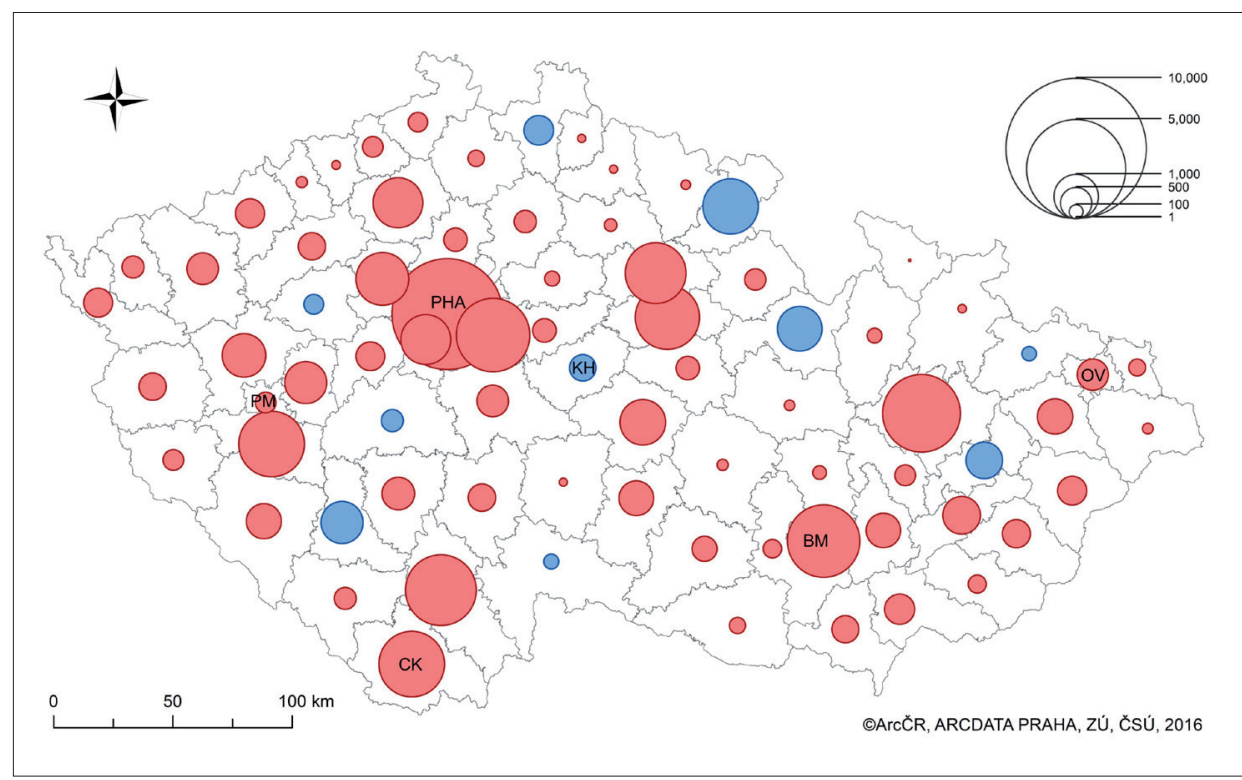

Fig. 5: Regional patterns of military employment reduction (1994-2005): absolute numbers. Notes: The map shows the difference between the cancelled military jobs and newly created jobs. Red figures mark districts with an overall decrease of military jobs between 1994 and 2005, blue districts experienced an overall increase of military jobs. PHA = Praha/Prague; $B M=$ Brno; $O V=$ Ostrava $; P M=$ Plzeň/Pilsen $; C K=$ Český Krumlov; KH = Kutná Hora Source: authors' compilation

Deviant cases can thus be mostly explained by contextual and contingent factors, such that they do not contest the validity of the model. On a general plane, it seems that while there was a clear pattern in reducing certain bases and units, it is less clear why certain units and bases have survived until today.

\section{Discussion}

Our basic empirical results are consistent with the comprehensive study of geographical aspects of demilitarisation in the Czech Republic provided by Hercik (2016). Hercik documented a gradual significant spatial concentration of military bases into the largest cities, an overall reduction of military functions in space, but also the growth of military employment in municipalities with less than 1,000 inhabitants in the military training areas located in highly peripheral areas (Frantál et al., 2020). As he stated:

"Between 1993 and 2015, the number of military bases decreased from 158 to 25 . A total of 105 crews were completely abandoned, which represents $79 \%$ of all military bases affected by relocation changes and $66 \%$ of all military bases in which the Czech Army was deployed at the time of its establishment. Approximately half of them were concentrated in the western third of the Czech Republic. In terms of the size structure of municipalities, more than $50 \%$ of closed military bases were located in municipalities with less than 10,000 inhabitants" (Hercik, 2016, p. 82).
He also documented the increasing median population size of municipalities with military bases, the increasing average size of military bases, and the concentration of commandand-control functions in the capital city of Prague.

"If in 1990 there were a total of 9 divisions and 27 brigades within the ground forces, in 2014 the Army of the Czech Republic no longer had any divisions. Only two brigades operated in the organisation of the ground troops (Hranice and Žatec)" (Hercik, 2016, p. 83).

Our empirical results suggest that the military base closure/ downsizing between 1994 and 2005 was highly erratic. It was not uncommon that relatively new or modernised military bases were closed, while the obsolete/inconvenient military bases were maintained. This explanation might be valid for the lack of an association between the hierarchy and demilitarisation.

More surprisingly, although the tanks, artillery, and armoured vehicles were reduced more than other units, the share of mechanised units of soldiers within districts showed no statistical effect on demilitarisation at the level of districts. This paradox can be explained by the relatively small number (19) of districts, where these heavy units were located in 1994. Only in six districts was the share of heavy units in total military personnel higher than $50 \%$. Also, heavily mechanised units (mostly tanks) are less "labour-intensive" and were based on conscripts rather than professional soldiers. Therefore, net employment loss resulting from 
closing military bases with mechanised units was limited. Finally, except for a few airborne and special forces battalions, almost all combat units were heavily mechanised. Instead of disbanding these units as a bloc, only part of them was disbanded, some were transformed into lighter units and a few continued as heavily mechanised units.

If we turn to the regional level, 'urban size' showed a positive effect on the intensity of demilitarisation in the Czech Republic. Nevertheless, there was probably no systematic regional policy behind it. The concentration of military bases into the largest cities (see Atkinson, 1993, for a similar trend in the USA) was rather driven by the strategic reorientation of the Czech Armed Forces associated with entry to NATO, by economic reasons favouring the spatial concentration of the defence sector in general (see Droff, Baumont and Barra, 2019 for the theory), and perhaps also by residential preferences (quality of life) of the commanders and soldiers (Rašek, 2002; Wheeler, 2016). On the other hand, many military bases were closed in large metropolitan areas to gain economic profits from the sale of lucrative real estate. Thus, regional aspects probably affected the military base closures primarily through ad-hoc lobbying of the deputies, mayors, or local commanders (these aspects are beyond the scope of this paper, however).

Maybe the most significant finding is that of no statistical relationship between regional economic performance (wages, unemployment) and demilitarisation. Correspondingly, the type of region (regional capital, old industrial, peripheral) played no role either. Military bases in economically lagging regions were protected neither to avoid social tensions nor to lower operating costs. While there were several isolated attempts to protect selected military bases in lagging regions, we failed to find any conclusive empirical evidence of regional policies preventing the demilitarisation in districts with low wages and high unemployment. This contrasts with the findings from the USA (Beaulier, Hall and Lynch, 2011) that military bases in high unemployment states were protected, while military bases in high unemployment (probably mostly rural) counties were more likely to be placed on the BRAC (Base Realignment and Closure) list.

While our aim was not to test specifically the effect of military base closure on regional (un)employment, no significant stabilisation effect of military presence on regional unemployment has been recorded: in contrast with the findings of Bernauer, Koubi and Ernst (2009) from Switzerland. Rather, our observations are closer to the findings of Paloyo, Vance and Vorell (2010) from Germany or Andersson et al. (2005) from Sweden, who both failed to find significant negative regional economic effects of military bases closures in their countries. In the Czech Republic, relatively low unemployment until the second half of the 1990s and a spatial mismatch between the 1990s regional unemployment growth and military base closure, may be other reasons as to why regional disparities did not affect the process of demilitarisation significantly.

By far the most important factor of demilitarisation was the combination of the initial level of militarisation (1994) and the distance from Nuremberg. Therefore, geostrategic reorientation and professionalisation of the military affected regional patterns of military base closure more than other processes. The reduction of excessive military bases mostly in the western part of the state and in metropolitan regions eclipsed the effects of other factors. We did not identify any systematic longer-term spatial change of defence prioritisation towards economically rapidly growing regions with high-tech industries that would be comparable to the Frostbelt-Sunbelt shift in the USA (Warf, 1997) or to the north-south shift in the UK (Lovering, 1991; Bishop and Gripaios, 1995; Bishop and Wiseman, 1999). In the Czech Republic, the shift from the Western part of the country to a dispersed pattern of military bases was geopolitically driven.

Finally, there are significant limitations relating to such kind of research in the post-socialist environment. In comparison with western scholars, Czech researchers are dealing with a lack of well-structured open data. Czech political and military institutions do not usually provide more detailed data. Our research could employ the data covering the spatial distribution of MBs for 1994 and 2005 only. Although the decline of military employment in the period 1994-2005 was certainly not linear, we were unable to obtain the yearly data necessary for proper panel data regressions (see Popert and Herzog, 2003). Instead, we had to rely on the basic OLS models capturing only the 1994-2005 change in militarisation as the dependent variable.

Besides, we were also unable to estimate several important factors of the MBs closure/downsizing. Most importantly, no systematic data covering the financial value of military buildings and equipment are available. Therefore, it is possible neither to calculate precisely potential exit sunk costs associated with the MBs closure, nor to quantify exactly the share of modern or obsolete tangible assets/equipment and their usability for current or future military purposes. In addition, the aggregation of the military data at the district level may obscure any potential differences between the MBs inside the district.

These limitations notwithstanding, an equally important issue deals with the generalisability of our main findings. In this respect, our study deals with a rather unique period marked by profound geopolitical changes and extreme demilitarisation. Current European trends in demilitarisation or militarisation, however, cannot be compared to the scale of changes we have investigated. As such our study may be generalisable to other CE countries in the 1990s and early 2000s but we warn against generalisations to the current decade or other world regions. The point is not to say that our findings have no bearing outside of the early post-cold war context, rather the point is to highlight that we have investigated an extreme case. Future studies should focus on current cases to provide a more nuanced picture of the key factors of demilitarisation (or remilitarisation) and their contextual significance.

\section{Conclusions}

While the studies dealing with regional economic impacts of military base closures are numerous, few authors focused on the question of to what extent regional economic disparities affect the process of military base closure and realignment. Drawing on a case study of demilitarisation in the Czech Republic (a country that has experienced in the last three decades probably the sharpest decline in military staff in the world), we tried to capture the geographies of demilitarisation in this post-socialist country. More specifically, we aimed to explain changes (1994-2005) in the spatial distribution of military bases, reflecting the geostrategic reorientation (entry to the NATO), restructuring, and professionalisation of the Czech Armed Forces.

Three groups of factors were tested through the regression models: (i) local (military base) characteristics; (ii) regional (economic disparities, the initial level of militarisation in 
the district); and (iii) national-level factors (geostrategic priorities, restructuring of the Czech Armed Forces). National-level factors played a key role. When combined with the existing spatial distribution of excessive military bases inherited from the socialist era and disproportionately concentrated in the western part of the country close to the borders with Germany, they explained more than half of the variability of 1994-2005 military staff reduction.

Regional wage and unemployment disparities, on the other hand, showed no significant correlation with the intensity of military base closures/downsizing. We did not find sufficient empirical evidence that military bases in economically lagging peripheral and old industrial regions had been systematically protected. This does not mean that regional/municipal interests had no significance. Nevertheless, they affected the fate of several military bases probably through individual actions, lobbying of politicians and mayors, or through the connection of the restitution of land. Besides, the highly erratic character of military base closure and realignment in the Czech Republic can be another explanation for this missing association. The large-scale restructuring of the Czech Armed Forces together with fundamental changes in geostrategic orientation eclipsed the effects of regional economic factors and the position of the military bases in the organisational hierarchy of the Army.

'Urban size' was related to demilitarisation in two ways: (i) several military bases in large cities (especially in the capital city) were closed as a result of the rent-seeking behaviour of the politicians that profited from the sale and conversion of lucrative land; (ii) military staff, command, and control functions have been gradually concentrated into larger cities. Therefore, potential reuse was among the key factors of the military base closure, but individuals - not the Czech Armed Forces - profited from the sales of land.

While political factors significantly affected the military base closure, we found no systematic difference between the economically lagging old industrial and peripheral regions and the metropolitan and other economically growing regions at the pace of demilitarisation. This contrasts with the situation in the USA, where the lobbying of individual congressmen was partly reduced by the establishment of an independent committee that proposed a list of military bases suggested for closure, the congressmen voted for/against the entire list, with no possibility to add or delete any bases from it (Mayer, 1995; Whicker and Giannatasio, 1996). The absence of this mechanism in the Czech Republic together with an immature institutional environment and legislative framework in the 1990 s provided too much space for individual rent-seeking behaviour and incompetent decisions. In contrast to the USA, the military in the Czech Republic plays a not so important role in politics. So, it is not worth lobbying for/against their presence in a particular region when there is not a hidden agenda, for instance, utilisation of real-estate left/run by the military.

\section{References:}

ATKINSON, R.D. (1993): Defense Spending Cuts and Regional Economic Impact. Economic Geography, 69(2): 107-122.

BÄCKSTRÖM, P. (2019): Are Economic Upturns Bad for Military Recruitment? A Study on Swedish Regional Data 2011-2015. Defence and Peace Economics, 30(7): 813-829.
BAŠTOVÁ, M., HUBÁČKOVÁ, V., FRANTÁL, B. (2011): Interregional differences in the Czech Republic, 2000 2008. Moravian Geographical Reports, 19(1): 2-16.

BEAULIER, S. A., HALL, J. C., LYNCH, A. K. (2011): The impact of political factors on military base closures. Journal of Economic Policy Reform, 14(4): 333-342.

BERNAUER, T., KOUBI, V., ERNST, F. (2009): National and regional economic consequences of Swiss defense spending. Journal of Peace Research, 46(4): 467-484.

BISHOP, P., GRIPAIOS, R. (1995): The Regional Impact of Cuts in UK Defense Spending. Defense Analysis, 11(2): 175-187.

BISHOP, P., WISEMAN, N. (1999): The north-south divide in the UK defence sector. Regional Studies, 33(9): 829-841.

BLAŽEK, J. (1996): Meziregionální rozdíly v České republice v transformačním období. Geografie-Sborník CGS, 101(4): 265-277.

BLAŽEK, J., CSANK, P. (2007): Nová fáze regionálního rozvoje v ČR? Sociologicky časopis/Czech Sociological Review, 43(5): 945-965.

BRADSHAW, T. K. (1999): Communities not fazed. Journal of the American Planning Association, 65(2): 193-206.

CAMERIN, F., GASTALDI, F. (2018): Italian military real estate assets re-use issues and opportunities in three capital cities. Land Use Policy, 78: 672-681.

CLARK, G. L., WRIGLEY, N. (2017): Sunk costs: A framework for economic geography. Economy: Critical Essays in Human Geography, 20(2): 241-260.

COBB, S. (1976): Defense Spending and Defense Voting in the House: An Empirical Study of an Aspect of the Military-Industrial Complex Thesis. American Journal of Sociology, 82(1): 163-182.

COBB, S. A. (1969): Defense spending and foreign policy in the House of Representatives. Journal of Conflict Resolution, 13(3): 358-369.

DVORAK, J., PERNICA, B. (2021): To free or not to free (ride): a comparative analysis of the NATO burdensharing in the Czech Republic and Lithuania - another insight into the issues of military performance in the Central and Eastern Europe. Defense \& Security Analysis, 37(2): 164-176.

DROFF, J., BAUMONT, C., BARRA, A. (2019): The Organization of the Defense Support System: An Economic Geography Perspective. Defence and Peace Economics, 30(2): 159-175.

EDMUNDS, T. (2006): What are armed forces for? the changing nature of military roles in Europe. International Affairs, 82(6): 1059-1075.

FORTUNA， M. J. A., TEIXEIRA， J. C. A., SILVA，F. J. F. (2021): Gone with the Winds of Peace: The Regional Economic Effects of Military Base Downsizings and Closures. Defence and Peace Economics, 1-24.

FRANTÁL, B., KUNC, J., JAŇUROVÁ, M., KREJČÍ, T. (2020): Problems of transforming military training areas in a post-communist space: Local community perceptions and policy implications. Transylvanian Review of Administrative Sciences, 16(59): 40-58.

FRAWLEY, K. (2006): Dependency on Military Base Employment's Effect on Defense Expenditure Voting in 
Congress : A BRAC Era Test of the Military Industrial Complex Theory. 11(1): 31-45.

HAMPL， M. (2005): Geografická organizace společnosti v České republice: transformační procesy. DemoArt, Praha.

HAMPL, M., MÜLLER, J. (2011): Společenská transformace a regionální diferenciace Česka: př́klad vývoje rozmístění. Geografie, 116(3): 211-230.

HERCIK, J. (2016). Demilitarizace území České republiky a její geografické aspekty. (Doctoral dissertation). Brno, Masarykova univerzita, Přírodovědecká fakulta).

HERCIK, J., SZCZYRBA, Z., FŇUKAL, M. (2011): Prostorové změny $\mathrm{v}$ dislokaci ozbrojených sil na území ČR. In: Městské inženýrství Karlovy Vary 2011 - "Od vojenského k civilnímu“ (pp. 109-123). Ostrava, VŠB-TU Ostrava.

KEHL, B. (2003): The Pentagon vs. Congress: the political economy of military base closures during BRAC. George Mason University, Fairfax.

KISS, Y. (1993): Lost Illusions? Defence Industry Conversion in Czechoslovakia, 1989-92. Europe-Asia Studies, 45(6): 1045-1069.

KISS, Y. (2000): Regional aspects of defense-industrial transformation in East-Central Europe. International Regional Science Review, 23(1): 120-131.

LINDSAY, J. M. (1991): Testing the Parochial Hypothesis: Congress and the Strategic Defense Initiative. The Journal of Politics, 53(3): 860-876.

LOVERING, J. (1991): The Changing Geography of the Military Industry in Britain. Regional Studies, 25(4): 279-293.

MAYER, K. R. (1995): Closing Military Bases (Finally): Solving Collective Dilemmas through Delegation. Legislative Studies Quarterly, 20(3): 393-413.

MCCAUSLAND, J. D. (1999): “Carts and Horses”-Strategy and Arms Control for a New Europe. The US Army War College Quarterly: Parameters, 29(1): 25-42.

MELACHROINOS, K. A., SPENCE, N. (2001): Conceptualizing sunk costs in economic geography: Cost recovery and the fluctuating value of fixed capital. Progress in Human Geography, 25(3): 347-364.

MOD1 (1994): Statistical Yearbook 1993. Praha, Military Office of Personal Information and Statistics.

MOD2 (2005): Statistical Yearbook 2005. Praha, Military Office of Personal Information and Statistics.

OLSON, M. (1971): The Logic of Collective Action: Public Goods and the Theory of Groups (Revised ed.). Harvard University Press.

PALOYO, A. R., VANCE, C., VORELL, M. (2010): The regional economic effects of military base realignments and closures in Germany. Defence and Peace Economics, 21(5-6): 567-579.
PARR, J. B. (2002): Agglomeration economies: Ambiguities and confusions. Environment and Planning A, 34(4): 717-731.

RAŠEK, A. (2002): Bezpečnostní politika České republiky při vstupu do Evropské unie. Vojenské rozhledy, 11(43): 3-23.

ROAF, M. J., ATOYAN, M. R., JOSHI, M. B., KROGULSKI, M. K. (2014): Regional Economic Issues - Special Report 25 Years of Transition: Post-Communist Europe and the IMF. International Monetary Fund. Washington, D.C.

SADYKIEWICZ, M. (1987): Soviet-Warsaw Pact Western Theater of Military Operations: Organization and Missions. Santa Monica.

SMĘTKOWSKI, M. (2013). Regional disparities in Central and Eastern European Countries: trends, drivers and prospects. Europe-Asia Studies, 65(8): 1529-1554.

SMITH, A. (1994): Uneven development and the restructuring of the armaments industry in Slovakia. Transactions of the Institute of British Geographers, 19(4): 404-424.

ŠTAIGL, J., TURZA, P. (2013a): 'Zbrojná výroba na Slovensku v rokoch 1969-1992 (1. čast'). Vojenská história, 17(2): 75-112.

ŠTAIGL, J., TURZA, P. (2013b): 'Zbrojná výroba na Slovensku v rokoch 1969-1992 (2. čast'). Vojenská história, 17(3): 77-109.

TMB (1989): The Military Balance. Pergamon Print.

TOMEŠ, J. (1996): Specifická nezaměstnanost v České republice v regionálním srovnání. Geografie-Sbornik CGS, 101(4): 278-395.

WARF, B. (1997): The geopolitics/geoeconomics of military base closures in the USA. Political Geography, 16(7): 541-563.

WHEELER, D. (2016): Back in BRAC: A Predictive model of military base realignments. University of La Verne.

WHICKER, M. L., GIANNATASIO, N. (1996): The politics of military base closings: A new theory of influence. Public Administration and Management, 1(1): 72-91.

ŽENKA, J., NOVOTNÝ, J., SLACH, O., KVĚTOŇ, V. (2015): Industrial specialization and economic performance: A case of Czech microregions. Norsk Geografisk Tidsskrift, 69(2): 67-79.

ŽENKA, J., PAVLÍK, A., SLACH, O. (2017): Resilience of metropolitan, urban and rural regions: a Central European perspective. GeoScape, 11(1): 25-40.

ZULLO, R., LIU, Y. (2017): Contending With Defense Industry Reallocations: A Literature Review of Relevant Factors. Economic Development Quarterly, 21(4): 360-372. 